\title{
Article \\ Policies to Reduce Child Poverty in Norway: Can Municipalities Ensure Positive Functionings for Children through Housing Policies?
}

\author{
Marit Kristine Helgesen * and Petter Arvesen
}

check for updates

Citation: Helgesen, M.K.; Arvesen, P. Policies to Reduce Child Poverty in Norway: Can Municipalities Ensure Positive Functionings for Children through Housing Policies? Societies 2022, 12, 25. https://doi.org/ $10.3390 / \operatorname{soc} 12010025$

Academic Editor: Gregor Wolbring

Received: 14 December 2021

Accepted: 8 February 2022

Published: 12 February 2022

Publisher's Note: MDPI stays neutral with regard to jurisdictional claims in published maps and institutional affiliations.

Copyright: (C) 2022 by the authors. Licensee MDPI, Basel, Switzerland. This article is an open access article distributed under the terms and conditions of the Creative Commons Attribution (CC BY) license (https:/ / creativecommons.org/licenses/by/ $4.0 /)$.
Department of Welfare, Management and Organisation, Faculty of Health, Welfare and Organisation, Østfold University College, 1757 Halden, Norway; petter.arvesen@hiof.no

* Correspondence: marit.k.helgesen@hiof.no

\begin{abstract}
Child poverty is an increasing challenge for Norwegian society and its municipalities. Policies to reduce it include housing as one particularly important health determinant. The capability approach allows us to focus on determinants for health. Methods were triangulated and literature and document studies, interviews and participating observations were part of the data-gathering process. Thematic analyses were used to analyse data. Children and adults view housing as important. Housing determines families' possibilities of consuming other goods and choosing what functionings they will convert their resources into. Municipalities can change the course of development by engaging with the Norwegian Government Housing Bank and implementing instruments such as social housing, housing allowances and starter loans giving families the possibility to become homeowners. Housing determines intra- as well as inter-generational life chances. Housing is a corrosive functioning if children live in families that have low-quality housing or high housing costs. Housing is a positive functioning for children if families own their housing. Housing is defined as a market good and a welfare asset. Policies enable some families to buy their own housing, whereas the number of poor children still increases.
\end{abstract}

Keywords: child poverty; housing policy; capabilities; determinants for health

\section{Introduction}

For every child, childhood is intrinsically valuable, and children have a right to a good life. Children are dependent on family resources, and if the family is poor, this affects children in material, social and psycho-social domains [1]. The effects of income poverty are inter-generational, and children living in poverty are substantially more likely to be poor as adults than non-poor children [2]. A special report to the EU Commission emphasises the importance of tackling the high rate of children living in poverty. Preventing child poverty is vital for the lives and futures of individual children, but also for the futures of societies and for economies. The report further states that the economic benefits of investing in children significantly outweigh the financing costs of the investment [3] (p. 8). Therefore, child poverty has drawn increasing attention from social scientists and policy makers in the past decades in the EU, and not the least in the Nordic countries and Norway [4].

Health and wellbeing in rich countries are related to relative income and social position, and poverty is considered to be highly contextual [4]. The economic poverty measures reflect this, and the OECD defines poverty as living with a disposable income that is less than $50 \%$ of the national median income [5]. EU sets the rate of relative poverty at $60 \%$ of the national median disposable income, and this is the Norwegian measure as well [6]. Poverty measures often focus on objective indicators such as income, wealth, goods and individual and family capabilities [7], but this should be avoided [8]. Rather, an alternative should be focused on, namely the means of living well and actual living that people manage to achieve, or the "freedom to achieve actual livings that one can have 
reason to value" [9] (p. 73). This is the capability approach. It is highly contextual [8] and allows for what Schweiger and Graf (2015) argue, namely considering the economic, social and political environment in which poverty is produced and reproduced. They further argue that contemporary knowledge on child poverty should inquire into the political economy and policy areas such as the labour market, public infrastructure, health care and education, and how national, regional and local institutions work to reduce it. The focus on children's wellbeing and the consequences of growing up in poverty must also recognise children as both "being", with ongoing lives, and individuals in the process of becoming future adults [10]. Applying the capability approach to child poverty has the potential to include both the present and the future lives of children in recognising their needs and capabilities [11].

In this paper, we focus on child poverty and housing policies. Housing is conceived to be a basic need in line with food and clothing and, as such, it influences life chances. Furthermore, housing is an important determinant for health [12]. However, it is a market good, and citizens are supposed to handle the market to acquire housing and keep it [13].

In Norway, housing costs are high [14]. As the capability approach enables inquiry into the political economy, it is necessary to point to this beyond relying on disposable income. Norwegian families rely on a comprehensive set of municipal services for children. For instance, in addition to all children going to school, about 92 percent of children attend kindergartens. Health centres are established, and public health nurses are employed in all municipalities, and all municipalities have access to child welfare services as well as educational services. Welfare services for adults are also accessible. However, UNICEF Norway, in their annual report on municipalities, showed that there are great differences between municipalities in how services for children are prioritised [15].

In this paper, we ask whether municipal housing policies can be an instrument to reduce child poverty. We use the capabilities approach as presented by Sen (1999) to discuss, first, how poor families and children view housing, i.e., whether they consider it a capability, and second, how a Norwegian municipality utilises the Norwegian Government Housing Bank instruments to perform housing policies, ensure housing for poor families and reduce child poverty.

The paper proceeds as follows: In the following paragraph, we present the Norwegian context, the actors and how they contribute. Next, we present the capabilities approach and how it can be applied to understand housing as an aspect of reducing child poverty. Thereafter, we present the methodology for data collection and analyses. Fourthly, we present the results, and fifthly, we discuss them. Lastly, we provide our conclusion.

\subsection{Norwegian Policies to Reduce Child Poverty and the Role of Housing}

Norway has ratified the Convention on the Rights of the Child and its paragraph 27 on children's right to a satisfactory standard of living and material welfare. Food, clothes and housing are named as central elements. Parents are given the responsibilities to secure the needed standard of living but should be granted help if necessary [16]. The UN social sustainability goal 11 target 1 , among others, says that everybody should be ensured access to adequate, safe and affordable housing [17]. Statistics Norway estimates about 23 percent of households to be tenant households in 2020; these households are renting in the private market and $56 \%$ of them have housing costs of $25 \%$ or more of their disposable income, which is the definition of having high housing costs [6,18]. In 2020, the mean cost of housing was $31 \%$ of all costs, a substantial increase from $14 \%$ during the last four decades [14]. Thus, housing costs are high, and in most OECD countries, median relative housing costs are higher for tenant households than they are for ownerwith-a-mortgage households, as is the case for low-income tenants in Norway [19]. Making tenant households homeowners would increase their disposable income and give them possibilities to choose what functionings they will prioritise for their children.

The reduction in child poverty has been on the Norwegian policy agenda for at least two decades, and in 2020, the Ministry of Children and Families (MCF) launched its second 
strategy to reduce child poverty, "Equal opportunities growing up", which is planned to last until 2023 [20]. The strategy's scope is broad, and it strengthens cooperation among the various actors involved at the national, regional and local levels. The strategy's chapters cover themes such as upbringing and care, housing, early intervention, participation in leisure activities, the reduction in social inequalities in the health of children and youth, and inclusion and work during adolescence and parenthood. Many instruments are listed, including increases in the child allowance, housing allowance, homeownership for the disadvantaged in the housing market, early intervention in kindergartens and schools, reducing drop-out rates from secondary schools, subsidies to local voluntary organisations, and the acquisition of new knowledge on how it is to grow up in low-income families and what measures, in fact, help [20].

The chapter devoted to housing is called "Stable living and safe neighbourhoods". The following four measures are listed to secure good housing for disadvantaged families: making a new strategy for social housing; strengthening tenant housing for disadvantaged families; providing housing support for disadvantaged families and area initiatives to upgrade neighbourhoods, among other things. Its point of departure is that a stable living environment ensures safe upbringings for children and adolescents [20].

In Norway, access to housing for all has played a major role in the post-war development of the welfare state, and Norwegian housing policy is based on homeownership [21]. This makes Norway similar to other Western countries promoting homeownership, with a belief in its role in ensuring individuals' economic security [8] (p. 257). From this perspective, housing is treated as a commodity, a market good and a means of accumulating wealth [22-24] and policies were adapted to a situation where developing housing was largely carried out by private enterprises [25]. A diverse set of instruments to strengthen municipal social housing were developed. Among them are housing allowances, starter loans and grants for individuals entering the housing market, and economic support and loans to municipalities and corporate actors to build tenant housing [18]. The instruments are administered by the Norwegian Government Housing Bank (NGHB), although municipalities decide on how to use them and prioritise between applicants for loans, grants and housing allowances. The loan instrument was strengthened in 2014 when the government implemented a regulation saying that starter loans should be reserved for those who are disadvantaged in the housing market. Municipalities aligned their practices with the regulation and to a greater extent than before, exploited the possibilities of the starter loan [26,27]. Dyb (2020) finds that the starter loan is an effective instrument to help the disadvantaged become homeowners and it may be used in innovative ways such as fixed rates, longer repayment periods, and individual adaptation [28,29].

The MCF strategy's instruments for transforming tenant households to homeowners are dependent on the NGHB strategy "Everyone needs a safe home (2021-2024)", which steers the bank's cooperation with municipalities. Its main goals are to make more people homeowners, ensure that tenant housing is a secure alternative, and make housing policies socially sustainable [18] (p. 9). Within this strategy, a program called "Children First" was established, encouraging municipalities to help low-income families become homeowners and follow up on the families admitted into the program. The main instruments are starter loans and grants to families $[29,30]$. Its aim within social policy is to motivate the families' adults to qualify for work. Within housing policies, it is to create safe and harmonious environments for children. Taken together, these aims are to break a negative social reproductive chain so that "instead of inheriting poverty, children will inherit property" $[18,27,29,30]$.

The Welfare Pilot Project (WPP) is carried out in one region in Norway as a collaborative initiative among regional state actors, and its main aim is to coordinate regional resources and accommodate the actors' coordinated communication with municipalities, i.e., "speaking with one voice with municipalities" [31]. The project is for coordinating communication with regard to instruments of financial and informational character. Collaboratively, in the relation between the regional actors, and in cooperation with the four municipalities taking part, the project concentrates on reducing child poverty, a theme 
considered timely in the region [31]. The WPP is owned by the County Governor (CG). All responsible regional actors taking part in the WPP are authorities of ministries implementing the MCF's strategy to reduce child poverty.

Administratively, Norway has 11 regions and 365 municipalities. Units at both levels are of varying size and municipalities range from less than 200 to more than 600,000 inhabitants. At the regional level, the CG represents the national level, coordinating national policies towards municipalities, and guiding and counselling them within the service areas assigned with the office. Furthermore, the CG controls some financial means for which municipalities may apply. Decisions for municipalities to receive means are based on the CG's discretional power. The CG's responsibilities are mostly administrative. Implementing the WPP, the CG collaborates with the welfare authorities, NAV, the Norwegian Government Housing Bank (NGHB) and The directorate for children, youth and families, Bufdir, named Bufetat at the regional level. These agencies have operational tasks. NAV is an agency within the responsibility of the Ministry of Labour and Social Affairs. It is represented at the regional and municipal levels, and the coordination between levels is formalised in partnerships. Bufdir is a subordinate agency of the Ministry of Children and Families. It works closely with municipal child welfare offices on certain tasks such as child protection and foster care. The NGHB is a subordinate agency of the Ministry of Local Government and Modernization. It administers instruments covering loans and grants to individuals (starter loans and housing grants), support for housing costs (housing support), and grants to private contractors or municipalities to build social housing.

The most important actors are the municipalities. They are both political entities and administer national policies at the local level. As such, they have the responsibility for providing services such as health, care, welfare, local planning and housing policies and thus, they operationalise and perform the WPP and align its goal with problem areas considered vital to them. In our case, these problem areas are child poverty and housing policies.

\subsection{Capabilities and Housing as a Fertile Functioning for Children}

Poverty is relative to the society in which an individual lives and makes the individual, family, group or community disadvantaged relative to others [2,8]. The capability approach allows researchers to investigate the economic, social and political environment that promotes poverty. Nussbaum argues that the capability approach focuses on individual dignity and how it is tightly knitted to living conditions that can provide people with "a life that is worthy of the human dignity that they possess" [32]. Sen (1999:75) defines a capability as "what a person is substantially free to do". In addition, he points to how capabilities focus on the freedoms generated by commodities [9] (p. 74). The approach considers whether individuals have different abilities to convert resources into valuable opportunities, outcomes or functionings [8] (p. 261). A capability is the ability to choose what to do and what to be and is closely connected to the individual's experience of freedom and wellbeing. Functionings are the outcomes individuals have the ability to convert resources into, and they reflect the various things a person may value doing or being, i.e., their achievements [9] (p. 75). Capability is "the substantive freedom to achieve alternative functioning combinations which reflects the person's actual achievements, and the capability set represents the alternative functioning combinations from which this person can choose" [9] (p. 75). To evaluate the freedom to achieve alternative functioning combinations, an account must be taken "not only of the primary goods the persons respectively hold, but also of the relevant personal characteristics that govern the conversion of primary goods into the person's ability to promote her ends" [9] (p. 74), i.e., the extent to which a person has real opportunities or abilities to choose valuable options. The substantive freedoms (the capabilities) to choose a life one has reason to value is the evaluative purpose, not the utilities or the primary goods themselves [9] (p. 74).

The capability approach is a normative evaluative approach, and it is "inescapably pluralist", as some functionings are more important than others and there is a question of 
what weight to attach to substantive freedom vis à vis the actual achievement [9] (p. 76). Having capabilities implies that the person has freedom to achieve valuable functionings as an active agent, and not because they have no other options or are coerced to do so [8] (p. 260). Thus, the notion of capabilities holds an agency assumption and presupposes that the subject in question is able to make autonomous decisions [7] (p. 28). As children are dependent and cannot use capabilities in the way adults can, and do not gain the same amount of value from having a choice when they are young [7] (p. 36), the goal for children may be to attain functionings that represent what children need to have a good childhood and to develop capabilities according to their age and stage of development. Thus, a realised functioning for children is what a child is actually able to do [9] (p. 77).

Advantages, and also disadvantages, may cluster with one (dis)advantage leading to another; that is, they corroborate. On the one hand, expensive and low-quality housing can negatively impact children's and adolescent's education, among other things, because families live in cramped conditions and there is no space to complete homework. Thus, housing is a functioning that may negatively impact other functionings. Statistics Norway estimates that 10.2 percent of households have cramped living conditions in Norway [33]. On the other hand, there is a positive association between homeownership and the educational attainment of children and adolescents, the cause of which is a more stable housing situation and not living in cramped conditions. In addition, homeownership and secure housing are important for families to translate their resources into fertile functionings for children [27,29]. Neighbourhoods composed mostly of homeowners are believed to be of better quality, as homeowners generally have a high degree of employment, and they are engaged with their environments. Such neighbourhoods may influence individual welfare due to the people available for social interaction and the role models they offer. Good physical environments such as areas for recuperation, and with only a little noise and air pollution add to the quality of neighbourhoods. Homeowners also have better health than tenant households, but high housing prices may affect health negatively [34].

High-quality housing can be a fertile functioning for children; for instance, there is evidence that it has a positive impact on both physical and mental health [35]. Health is also an example of a functioning that has a universally fertile effect [7] (p. 73). However, what are considered fertile functionings for children are context-dependent and, thus, dependent on how the institutions of society are shaped.

The capability approach, as outlined by Sen, does not indicate that housing is a capability, whereas Nussbaum's concept does, as she explicitly points to bodily health (i.e., being able to have good health, including reproductive health, being adequately nourished, and having adequate shelter) as one of her ten capabilities [32]. According to Sen, the goal is not that everybody shall live safely, rather that everybody has the possibility to do so. The question is whether a family has the real possibility of transforming resources and choosing the functioning of living safely according to existing norms for housing and the necessary consumption of other commodities [22]. According to the authors, if the families do not have this, they are disadvantaged in the housing market. This term is widely in use to denote people who are not able to handle the housing market. Those who are disadvantaged are the elderly, disabled individuals, low-income families and newly arrived immigrants. Both Sen (1999) and Nussbaum (2011) place the responsibilities for securing capabilities at the level of the nation state. Schweiger and Graf (2015) reach out more broadly and also include sub-national entities, families, groups and individuals as being responsible. Kimhur (2020) and Monkerud et al. (2018) hold that housing may be counted among the important functionings (capabilities), and in Norway, there is a housing policy that involves the national, regional and local levels.

\section{Materials and Methods}

The methodological research strategy in the paper is explorative, and elements from both action research and ethnographic follow-up research were used [36]. The methods were triangulated, and documents, literature studies, interviews and participating obser- 
vations were part of the data-gathering process. We also used some quantitative data to underpin our arguments. The process was dynamic and combined a pragmatic approach with reflection.

Literature studies were conducted on child poverty and the concepts of capabilities and the functionings for children and housing. The main aim is not to carry out a comprehensive study and interpretation of the literature related to our particular question [37], but to connect the concepts by framing them in a political economy context and to create a backdrop for data presentation and discussions [38]. The main search words were child poverty (in Norwegian-“barnefattigdom"), capabilities and housing. They were searched separately and together using the Boolean operators "AND" and "OR". Document studies were carried out according to national strategy documents and WPP meeting minutes, which were supposed to be written and placed on a Teams site. The site was not in use all the time, but minutes were read when found. The literature includes two master theses, one focusing on single mothers' experiences with public housing, and the other focusing on migrant families' experiences with receiving starter loans to buy housing. Both use interviews with families as their main method of data collection.

The observation and interview data were retrieved from evaluating the WPP. The researchers observed weekly meetings between the actors presented for the first year of the project. Meetings were assessed to be of certain importance concerning child poverty. The meetings observed also included those between regional actors and municipalities, including, for instance, start-up and follow-up meetings with municipalities. Workshops in municipalities gathering various municipal actors were attended. In these events, researchers generally observed the conversation and discussions among the participants, took notes, talked with them and, inspired by the action research elements, provided some feedback and delivered input to the project on selected topics such as child poverty and the project's implementation. Thus, researchers took on the role of an additional resource for the developmental work [39].

Thirdly, researchers conducted ten interviews with representatives from the regional agencies and the partaking municipalities, five in real-life settings and five during Teams sessions. The interview guide was semi-structured, covering themes such as the actual coordination and cooperation at the regional level, between the regional and municipal level and in municipalities, and professional and individual attitudes towards coordination. Furthermore, interviews were used to discuss the chosen problem formulations made by municipalities. The reduction in child poverty was a common aim, but the chosen approach differed among them. Interviews were transcribed in their entirety and thematic analyses were carried out [40]. Observations of follow-up meetings and interviews showed that two out of four municipalities were not able to anchor the project within their organisation and their participation slowly receded. The third chose to focus on project portfolio follow-up to ensure that different agencies were not working on similar projects in parallel, and operated mostly at the strategical level in the municipal organisation. Therefore, we present the results from one municipality.

The study was approved by the Norwegian Centre for Research Data (ref. no. 565707). Information on the study was provided both in writing and orally to managers of the CG and the municipalities, as well as to interviewees, who also signed a written consent waiver. The interviewees' right to withdraw from the study at any given time was emphasised.

\section{Results}

Children in poverty experience vulnerabilities that, to some extent, are socially created. Vulnerabilities are material because children, more often than others, live in low-quality housing in deprived neighbourhoods and lack the resources to consume material things in line with their peers [41]. In addition, children living in poverty miss out on participating in social and cultural activities. This makes them relatively deprived, which is important in explaining health inequalities. Even though children are agents in their own lives, they are dependent on adults. This makes children politically vulnerable because they cannot fight 
for their rights in the way adults can, and they cannot organise themselves in a comparable manner that would ensure them political influence and change their political position. Children depend on the rights they are granted by others [7].

We first present families' opinions on living in public housing and becoming homeowners and children's opinions on housing and housing environments. Information on this is retrieved from two master's theses [42,43] and the Norwegian Save The Children hearing on child poverty [20]. Thereafter, we analyse how one municipality negotiates utilising the national instruments to ensure housing and homeownership for poor families. Information on this was retrieved from evaluating the WPP.

\subsection{Children and Families' Opinions on Housing and Homeownership}

In 2019, about 179,000 persons were counted among those who are disadvantaged in the housing market; among them, $72 \%(129,111)$ were households with children. The number of disadvantaged families in the housing market has increased $[17,19]$. The OECD's mean of people having difficulties making ends meet in 2018 was about 22\%, whereas in Norway it was about $8 \%$ ([5], Figure 2.5). Nevertheless, 115,000 children were living in poverty in Norway in 2019; this is about $12 \%$ of all children [33]. To depict this, we used some data from the 2019 Norwegian EU-SILC survey. Respondents' answered that at the age of $1419 \%$ of them did not live with both their parents, $2.7 \%$ did not have all the necessary materials for school, and $16.8 \%$ did not usually go on vacation, with the reason for this being their economic situation [44]. Families in public housing most often consider their housing situation to be satisfactory, but the small size is considered a challenge. Immigrant families with children are overrepresented among those living in public housing and most live in cramped conditions.

Families living in public housing report more challenges, such as the housing situation feeling unsafe, although it feels safer than private tenant housing. The EU-SILC survey shows that insecurity may pertain to both noise from neighbours, roads and industrial activities nearby $(10 \%)$ and living in an area with crime and violence (4\%) [44]. Interviewed persons talked about public housing as being difficult to acquire, time consuming to apply for, and that it takes a long time to get a positive answer. Furthermore, families report living in cramped conditions, as about $10 \%$ of people do nationwide [33]. The result is that children, for instance, have no possibility of bringing friends home, and they live in worn houses [40]. An example is shown in the quotation below:

The friends are not many here. I want them to, but they [the children] say they don't have their own rooms and that makes it difficult. The two youngest share their room and the room's not good. We visit friends and they live in nice houses and the children have their own rooms. I have been looking at nice houses, but I don't have the economic means. It is difficult. (42:43)

This family wants to give their children good housing and opportunities, and children having their own room is part of that. The family members compare themselves to friends living in better housing and have tried to find this for themselves, but they consider it to be too costly. Living in public housing leaves families with no opportunity to save money; nonetheless, they consider buying their own homes important, both for housing and financial safety, as well as for taking part in the accumulation of wealth that is open to those who own their housing. The below quote is an example:

When you rent from the municipality, money is thrown out of the window. Nothing comes from that. If you buy housing, you pay to the bank and to yourself. (43:46)

An immigrant to Norway reflected on how buying a flat was taking part in economic growth, and as securing future housing for the family's children:

The flat is not for us, it's for the children. They will inherit it. It ensures the coming generation. (43:49) 
The inter-generational aspect is also well known to children, and they comment that inheriting money can give them a good start:

People who have a lot of money inherit a lot and can buy a house and all. A good start.

(20, Save The Children, hearing: 48)

This good start is not something they believe they will experience themselves, and they express full awareness that they are poor and that they will continue to be so during adulthood:

Yes, we have fewer opportunities. Because, then I think that "this will be my situation when I'm grown up as well". Because this is how it is for me in my family. (20, Save The Children, hearing: 170)

The financial and inter-generational aspects of being a homeowner are very clear to these interviewees and to the children taking part in the Save The Children hearing on poverty.

Interviewees in the master's theses suggest that being homeowners promotes integration because immigrants can then acquire the same commodities as Norwegians:

I feel glad and proud. I feel part of the society. On the same level as the Norwegians born here. I have a flat and a car-the same as the others. (43:49)

The immigrant families receiving starter loans had different experiences with the application process in their respective municipalities. Nevertheless, they experienced it to be a relief because they became homeowners. Paying the loan was positive as it integrated them into Norwegian society.

The Children World Report (2020) shows that Norwegian children aged 10 are fairly satisfied with their house and somewhat less satisfied with the neighbourhood in which they live compared to children in other countries [45] (pp:81,84). The interviewees in the master's theses report that the neighbourhood is critical for leading a good life and that the municipal housing service does not think much about what kind of families and persons live in the neighbourhood when housing is assigned. It may feel unsafe both inhouse, as neighbours, for instance, do not tolerate noises from children playing in the flat, and outside, because the police are called to the neighbourhood almost every day [42] (p. 48). Children themselves also have an opinion on the neighbourhood, as shown in the quote below:

If you live in a house in a good area. Some other person lives in a cheaper area. It is easier to live in the area with high income. The environments may be bad in the area with cheaper housing and the children may get into trouble. (20, Save The Children, hearing: 50/176)

Children feel unsafe and are afraid they will get into trouble if they live in a degraded neighbourhood, and they think it is easier to live in a neighbourhood where inhabitants have a high income. They compare the situations and are fully aware of the downsides of living in a cheap area. Other aspects about the neighbourhood are the housing's proximity to public transport, as well as to services and leisure activities for children. The last point was particularly important:

I don't have the financial means to pay so that all children can go by bus to take part in their leisure activities. (42:46-47)

Housing is an expensive good for most families. The data show that families are not particularly satisfied with being a tenant household, as high rent impacts their possibility to consume other necessary commodities. Intra-generationally, living in a poor family may hinder children's ability to feel safe, and low-quality housing may hinder them from having friends over to visit, using public transport and taking part in leisure activities. There is also the negative aspect of having to compare oneself to better-off friends, which may impact the mental health of children. We also know that living in cramped conditions may influence children's schoolwork and their educational attainment. This impacts what capabilities 
they can attain as adults. The quotes show that families do not have the possibility of choosing what functionings for their children they will translate their resources into. In the next section, we will present the work of one municipality to actually reduce child poverty by strengthening their social housing policies.

\subsection{Municipal Policies to Ensure Housing for Poor Families}

The municipality from which we have data is medium sized with about 30,000 inhabitants. It has previously taken part in NGHB projects and is well acquainted with the possibilities offered. Previous projects reported the challenges experienced by the municipality's population of people who are disadvantaged in the housing market and created knowledge on the municipality's working routines for allocating starter loans, social housing and housing allowances. These routines did not perform well at reducing child poverty. Reports looked into the following:

[...] how the allocation of social housing looks. Starter loans; to whom do we allocate starter loans and what are our routines on this? Routines were found not to function according to the aims of the WPP. Now, the focus has changed. (Municipal respondent 3)

In this municipality, the decision on the direction of the housing policy was made when we started observing meetings. In municipality 2, however, we observed discussions between advocates for strengthening public housing for the elderly on the one hand, and for families with children on the other.

In addition, the previous participation in NGHB projects made municipality 3 associate housing with early intervention for children and youth, which we did not observe in any of the other municipalities:

[...] if we consider social housing, ... we had three action plans. [...] To focus on housing and the Housing Bank program to support municipalities. Early intervention, related to the co-located family services, and linked to our housing policies. [...] Voluntary work is the third action plan. (Municipal respondent 3)

Implementing the WPP, the municipality decided that reducing child poverty should be a goal, and that starting to work with the NGHB instruments was the solution. This represented a change, as social housing was mostly allocated to the disadvantaged elderly. Changing the routines for the allocation of starter loans was commented on as follows:

[We] involved the manager of the joint services office. [...] We discussed our practise on this and how to improve [the use of starter loans]. Low-income families are the focus of the WPP. [...] The manager committed to the new mindset about the allocation of starter loans to low-income families. (Municipal respondent 3)

The adaptation to the new national regulations and the WPP frame housing policies as being tightly connected to early intervention. Its location within the child welfare and the municipal NAV unit, co-located with the family service department that also comprises community nurses and educational services, contributes to this perspective. The quote below shows how the municipal WPP coordinator is preoccupied by this framing:

Well, there are a lot of things that need to be sewed together to accomplish early intervention and to consider our work with it. WPP was very right for us when it started, inspiring the municipality-level system to consider the challenges. (Municipal respondent 3)

From this, we may read that being involved firstly with the NGHB and thereafter with the WPP, in which the NGHB is a prominent part, made the municipality change and improve its practices regarding starter loans and promoting homeownership among low-income families. It also led to changed practices regarding building and allocating social housing:

The Housing Bank can economically support housing developers to build housing for which the municipality is allowed to allocate some of the units. The CEO has chosen, through WPP, to coordinate this. (Municipal respondent 3) 
Furthermore, the CEO, leading the municipal administration, wanted the WPP coordinator to write a report on social housing for the municipal council. The interviewee supported this as it was believed to change the municipal attitude towards social housing:

This changes a lot, considering [social housing] as a municipal service. [...] We have never before allocated so many housing units to low-income families as last year. (Municipal respondent 3)

Some public debate on social housing led the assistant mayor to take part in one of the meetings with the NGHB. The meeting was successful, and the municipality was credited with performing well in this regard:

Then, the politicians became interested, that's nice. [...] The assistant mayor has now asked the responsible Municipal Director to orient the political committee on the case. (Municipal respondent 3)

This is the Committee for Teaching, Upbringing and Culture. Giving an orientation means that the WPP and its problematization of child poverty and housing are set on the political agenda. Hence, the interpretation of child poverty and housing as an early intervention and a set of policies for families, children and youth is distributed among more actors. Nevertheless, it is understandable that the director responsible for municipal property wondered why the department should be involved:

[...] the first time we oriented about the WPP, one of the municipal directors said: "What on Earth do we have to do with this? We are working with construction and things". Yeah ok, that is what you do. You work with municipal properties. So, I know that the CEO answered him "You are in fact [a member of] the steering group". [...] The actual Municipal Director left the meeting saying "Oh, now I have a lot to do". (Municipal respondent 3)

The ongoing collaboration between the municipality and the NGHB changed the involved actors' mindsets on how they interpret challenges concerning child poverty. Homeownership, social housing, property development, starter loans and housing allowances connected to early intervention constituted the new interpretation. Hence, the department in question was needed as a member of the steering group as well as an active member in the municipal WPP, and this membership contributed to the success. Taking part in the regional WPP accelerated the municipality's turnaround in considering these instruments to reduce child poverty. Working with the CG and diving deeper into the cooperation with the NGHB (a result of taking part in the WPP) was important in raising the issue of child poverty to the municipal political and administrative agendas, and also in receiving acceptance for reframing housing policies away from prioritizing the elderly to prioritizing children and youth. This way, the municipal actors also managed to change the way important local institutions functioned, allowing families with children to be part of the inter-generational accumulation of fortune associated with homeownership.

\section{Discussion}

The research question was whether municipal housing policies can be an instrument to reduce child poverty. We used the capability approach, which states that a person should have real opportunities or abilities to choose options they consider valuable. For children, the agency component of the capability approach implicated that the concept of functionings is used to understand their situation, both as children and future adults [11]. Functionings should pertain to what can be aspired to, or a goal that should be reached [7] (p. 43). What children can achieve, be and become as a result of their housing situation, is the vital point. If families experience an overburden of housing costs, cramped living conditions, low-quality housing or housing located in a deprived neighbourhood, they have few opportunities to choose what combinations of functionings they want for their children. 
Low-quality housing and housing that is too expensive were considered forms of corrosive functioning. The children of poor families living in social housing, and/or those that have high housing costs, were missing out on daily activities normal for children. As shown by Andresen and Meiland (2019), housing is perceived as an existential challenge to children. This covers the direct state of the housing unit such as size, amenities, rooms, and having their own room. They found that it is important to children to have a space of their own, as this encourages their learning and development. In addition, the housing may be too damp or worn, and this impacts the space available to play and recuperate. Our data show that children did not want to have friends over and that families compared themselves to friends who were better off. As low prices often equal low quality, disadvantages are found in both the housing itself and the residential environments. Low quality may mean that the environment and the socio-spatial structure of the area in which a family lives is not child-friendly, and areas may not supply services, including culture and outdoor spaces for recreation. Living in such environments will have intra-generational implications and restrict children's opportunities [1]. Missing out on what is customary creates shame [9] and it was shown that children missed out on simple activities such as taking public transport, taking part in leisure activities and building friendships. Furthermore, the families missed out on the intergenerational acquisition of wealth. Children could not expect to inherit property; on the contrary, they expected to inherit poverty.

When housing costs are high, families do not have the possibility to choose among alternative sets of functionings for their children. Thus, children's possibilities to acquire adult capabilities will be limited, particularly those concerning educational attainments, and they will not take part in the inter-generational accumulation of wealth. The NGHB and municipalities have the possibilities to change this course of developments. Data show that municipal authorities co-working with the NGHB are able to reduce child poverty. Municipalities can apply for and receive subsidies from the bank. Subsidies can be used to enter into negotiations with developers to build social housing, and thus, the municipalities can allocate a certain number of housing units to those who are disadvantaged in the housing market. Subsidies can also be used to allocate starter loans to the disadvantaged, pay housing allowances and provide grants to families entering into the Children First programme. NGHB statistics show that huge amounts of money have been paid to subsidy starter loans and housing allowances since 2011, and that these instruments in 2021 were in use in 328 municipalities, including the four municipalities that are part of the WPP [46]. Most municipalities make use of starter loans and housing allowances, and families with children are among the subsidised households. This indicates there has been success in the work to change the mindset underpinning the housing policy to include a new target group, i.e., children and youth. Framing housing policies by linking housing to other functionings in a positive way makes it an important factor influencing the target group's life chances.

However, housing has a different status than health, education and work, as it is described as "the wobbly pillar under the welfare state" [47]. It has also been referred to as "the sore spot of social democracy" [20]. There are several factors that mark out the complexity and ambiguity of housing policies. The housing market is weakly regulated and characterised by large geographical variations. Furthermore, the primary and secondary consequences of the use of instruments such as starter loans are complex both for the families and for the housing market, reinforcing the problems they were meant to solve [21]. In addition, the effort requires coordination between different municipal service sectors, and between municipal and regional actors such as the NGHB and the County Governor. The scope and complexity of housing policies can be described as a "wicked problem" [48]. A "wicked problem" is characterised by its complexity, that it has no easily definable solutions, and that it spans organizational boundaries, management areas and hierarchical levels [49]. Coordination between government agencies is, as we have shown, an important tool for dealing with these challenges [49].

As we have argued, when considering the complexity of housing as potential functionings for poor families and children's lives, we must further consider a wider range of 
capabilities of housing, both for poor children's wellbeing, and in the inter-generational focus on how to prevent the reproduction of poverty. Aside from housing being a basic good and the potential of transferring assets to the next generation, there are two perspectives on housing that can be prominent in this regard [50]. First, for most people, housing is found and bought on the market, resembling a common consumer good, and people have different desires and preferences. Therefore, the capability to choose what combinations of functionings they want for their children is important. Secondly, the house is a status symbol and positional marker. Norway is the "owner's country", and not owning your home can be stigmatising, and this is independent of the location and the standard of the house [51]. In this sense, owning a smaller house can be preferred before renting a larger one. Furthermore, instruments such as starter loans will depend on access to suitable housing in the local housing market. This means that the house as a wealth object and status symbol may vary both nationally and locally. This dependence on the market can lead to a limited assessment of available objects and searching for affordable housing may be a risk following already-established socioeconomic differences. Moreover, there are mechanisms in the market that can make families vulnerable. Changes in housing costs such as an increased interest rate can make families dependent on financial support measures that, in turn, can limit the functioning of housing.

\section{Conclusions}

To our question in the paper's title, we can answer "yes; municipalities can ensure positive functionings for children through housing policies". Local governments deciding to conduct housing policies by adopting one of the two NGHB programmes can contribute to strengthening families' resources to convert primary goods (housing) into abilities to promote their ends. Intra-generationally, children may experience possibilities to lead a life in which they can have a space of their own to complete homework, have friends over and take the bus to take part in leisure activities. They can experience educational attainment and compare themselves to their friends without feeling shame. Inter-generationally, families are enabled to take part in wealth accumulation through housing, giving children the opportunity to inherit property, not poverty, and acquiring prioritised adult capabilities by being better educated.

Nevertheless, as housing is an important functioning for children and can ensure them adult capabilities, the housing policies conducted are a result of housing being defined as a market good and a welfare asset. The responsibility to acquire housing is individualised, and the challenges many experiences are a result of the de-regulation of the housing market and the labour market. These two de-regulations happen simultaneously with the reregulation of the mortgage credit, limiting lending practices and increasingly shutting out those with little savings or precarious employment. The policies thus enable some families to buy their own housing while the number of poor children still increases.

Author Contributions: Conceptualisation: M.K.H. and P.A.; methodology: P.A. and M.K.H.; formal analysis: M.K.H. and P.A.; investigation: M.K.H. and P.A.; writing-original draft preparation: M.K.H. and P.A.; writing-review and editing: M.K.H. and P.A.; project administration: P.A. and M.K.H. All authors have read and agreed to the published version of the manuscript.

Funding: This research received no external funding.

Institutional Review Board Statement: Approved by the Norwegian Centre for Research Data (ref.no 565707).

Informed Consent Statement: Informed consent was obtained from all subjects involved in the study.

Data Availability Statement: Data available with researchers.

Conflicts of Interest: The authors declare no conflict of interest. 


\section{References}

1. Andresen, S.; Meiland, M. Being poor from children's point of view. The potential of childhood theory and qualitative methods for child poverty research: Findings from two qualitative studies of poverty in Germany. Child. Youth Serv. Rev. 2019, 97, 94-99. [CrossRef]

2. Redmond, G.; Skattebol, J. Material deprivation and capability deprivation in the midst of affluence: The case of young people in Australia. Child. Youth Serv. Rev. 2019, 97, 36-48. [CrossRef]

3. European Court of Auditors Special Report. Combating Child Poverty-Better Targeting of Commission Support Required. 2020. Available online: https:/ / www.eca.europa.eu/en/Pages/DocItem.aspx?did=54614 (accessed on 17 January 2022).

4. Povlsen, L.; Regber, S.; Fosse, E.; Karlsson, E.L.; Gunnarsdottir, H. Economic poverty among children and adolescents in the Nordic countries. Scand. J. Public Health 2018, 46 (Suppl. 20), 30-37. [CrossRef] [PubMed]

5. OECD. 2020. Available online: https:/ / www.oecd.org/statistics/how-s-life-23089679.htm (accessed on 7 May 2021).

6. Statistics Norway. 2021. Available online: https://www.ssb.no/bygg-bolig-og-eiendom/bolig-og-boforhold/statistikk/ boforhold-registerbasert (accessed on 11 June 2021).

7. Schweiger, G.; Graf, G. A Philosophical Examination of Social Justice and Child Poverty; Houndsmills, Palgrave MacMillan: London, UK, 2015. [CrossRef]

8. Kimhur, B. How to Apply the Capability Approach to Housing Policy? Concepts, Theories and Challenges. Hous. Theory Soc. 2020, 37, 257-277. [CrossRef]

9. Sen, A. Development as Freedom; Knopf: New York, NY, USA; Oxford University Press: Oxford, UK, 1999.

10. James, A.; Jenks, C.; Prout, A. Theorizing Childhood; Polity Press: Cambridge, UK, 1998.

11. Domínguez-Serrano, M.; del Moral-Espín, L.; Gálvez Muñoz, L. A well-being of their own: Children's perspectives of well-being from the capabilities approach. Childhood 2019, 26, 22-38. [CrossRef]

12. Whitehead, M.; Dahlgren, G. Concepts and Principles for Tackling Social Inequities in Health: Levelling Up. Part 1; World Health Organization: Copenhagen, Denmark, 2006.

13. Flåto, M. Knowledge, policy and practice-Governing homelessness in Norway. In Thesis Submitted to Department of Social Work, Child Welfare and Social Policy; Oslo Metropolitan University: Oslo, Norway, 2022.

14. Meld. St. Melding til Stortinget. Perspektivmeldingen; Finansdepartementet: Oslo, Norway, 2021.

15. UNICEF Norway. Analysis of Municipalities 2021. All Children Have the Right to a Safe Growing Up; UNICEF Norway: Oslo, Norway, 2021. Available online: https://www.unicef.no/sites/default/files/2021-08/Kommuneanalysen_2021_UNICEF_0.pdf (accessed on 14 August 2021).

16. Ministry on Children and Families. UNs Convention on the Rights of the Child; Ministry on Children and Families: Oslo, Norway, 2003. Available online: https://www.regjeringen.no/globalassets/upload/kilde/bfd/bro/2004/0004/ddd/pdfv/178931-fns_ barnekonvensjon.pdf (accessed on 14 August 2021).

17. UN. Available online: https://sdgs.un.org/goals/goal11 (accessed on 14 August 2021).

18. Kommunal-og Moderniserings Departementet. Alle Trenger et Trygt Hjem. Nasjonal Strategi for den Sosiale Boligpolitikken. 2020. Available online: https://www.regjeringen.no/no/tema/plan-bygg-og-eiendom/boligmarkedet/boligsosial-strategi/ id2786896/ (accessed on 14 August 2021).

19. OECD. Housing Costs over Income. 2020. Available online: https://www.oecd.org/els/family/HC1-2-Housing-costs-overincome.pdf (accessed on 7 May 2021).

20. Ministry of Children and Families. Equal Opportunities Growing Up. Strategy to Reduce Child Poverty in Norway; The Ministry of Children and Families: Oslo, Norway, 2020.

21. Sørvoll, J. Forskningen på boligsosiale virkemidler rettet mot vanskeligstilte på boligmarkedet i Norge 2005-2018. Tidsskr. Boligforskning 2018, 45-66. [CrossRef]

22. Monkerud, L.C.; Astrup, K.; Nordvik, V. Omfanget av Vanskeligstilte på Boligmarkedet_En Kapabilitetstilnærming; NIBR-Rapport 2018:18; By-og Regionforskningsinstituttet: Oslo, Norway, 2018.

23. Arundel, R. Equity-Inequity: Housing Wealth Inequality, Inter and Inter-generational Divergences, and the Rise of Private Landlordism. Housing, Theory Soc. 2017, 34, 176-200. [CrossRef]

24. St.meld. nr. Om Boligpolitikken; Kommunal-og Moderniserings Departementet: Oslo, Norway, 2004.

25. Nordahl, B. Boligmarked i Endring. I Nordahl (Red.), Boligmarked og Boligpolitikk; Akademika Forlag: Trondheim, Norway, 2012.

26. Astrup, K.; Monkerud, L.C. Den Økonomiske Fordelen av Overgangen fra Leie til eie for Utsatte Husstander; NIBR-Rapport 2021:5; By-og Regionforskningsinstituttet: Oslo, Norway, 2019.

27. Holt, E.; Syvertsen, T. Vanskeligstilte barnefamiliers vei til egen eid bolig. Innovativ bruk av startlån i det boligsosiale arbeidet. Tidsskr. Boligforskning 2021, 75-86. [CrossRef]

28. Dyb, E. Lykken ved å eie sin bolig. Tilfredshet og sosial integrasjon blant eiere og leietakere. Tidsskr. Boligforskning 2020, 32-50. [CrossRef]

29. Holm, A.; Nygaard, M.; Bråthen, A.; Løyland, H.I.; Asphaug, L.; Asphjell, M.K. Evaluering av Barna Først: Husbankens Virkemidler for å få Barnefamilier fra leie til eie; OsloEconomics og by-og Regionforskningsinstituttet, NIBR: Oslo, Norway, 2020.

30. Husbanken. 2020. Available online: https://www.husbanken.no/boligsosialt-arbeid/barna-forst/ (accessed on 21 June 2021).

31. Arvesen, P.; Helgesen, M.; Fineide, M.J.; Ørmen, N. Horisontal og Vertikal Samordning Mellom Regionale og Kommunale Aktører i Arbeidet mot Barnefattigdom -Kan Velferdspiloten vise vei? Oppdragsrapport 2021:1; Høgskolen i Østfold: Fredrikstad, Norway, 2021. 
32. Nussbaum, M.C. Creating Capabilities. The Human Development Approach; The Belknap Press of Harvard University Press: Cambridge, MA, USA, 2011.

33. Epland, J.; Normann, T.M. 115000 Barn I Husholdninger Med Vedvarende Lavinntekt; Statistics Norway: Oslo, Norway, 2021. Available online: https:/ / www.ssb.no/inntekt-og-forbruk/artikler-og-publikasjoner/115-000-barn-i-husholdninger-med-vedvarendelavinntekt (accessed on 9 September 2021).

34. Umblijs, J.; von Simson, K.; Mohn, F. Boligens Betydning for Annen Velferd. En Gjennomgang av Nasjonal og Internasjonal Forskning; Rapport 2019:1; Institutt for samfunnsforskning: Oslo, Norway, 2019.

35. Helgesen, M.; Holm, A.; Monkerud, L.C.; Schmidt, L. Folkehelseperspektiv i Boligpolitikken? NIBR-Rapport: 2014:16; Norsk Institutt for by-og Regionforskning: Oslo, Norway, 2014. Available online: https:/ / oda.oslomet.no/oda-xmlui/handle/20.500.12199/5917 (accessed on 9 September 2021).

36. Hammersley, M.; Atkinson, P. Feltmetodikk. Grunnlaget for Feltarbeid og Feltforskning; Ad Notam Gyldendal: Oslo, Norway, 1998.

37. Aveyard, H. Doing a Literature Review in Health and Social Care. A Practical Guide; Open University Press: London, UK, 2019.

38. Tjora, A. Qualitative Research as Stepwise-Deductive Induction; Routledge: Oxford, UK, 2019.

39. Sverdrup, S. Evaluering. Faser, Design og Gjennomføring; Vigmostad \& Bjørke AS: Oslo, Norway, 2014.

40. Braun, V.; Clarke, V. Using thematic analysis in psychology. Qual. Res. Psychol. 2006, 3, 77-101. [CrossRef]

41. Main, G.; Bradshaw, J. Child poverty in the UK: Measures, prevalence and intra-household sharing. Crit. Soc. Policy 2016, 36, 38-61. [CrossRef]

42. Juterud, E. Nei, jeg Orker ikke å Flytte Igjen! En Kvalitativ Studie om Hvordan Enslige Mødre Opplever å bo i Kommunal Utleiebolig. Master's Thesis, Universitetet i Sørøst-Norge, Notodden, Norway, 2020.

43. Kirsebom, S.J. Eie Først, det Betyr nytt liv. En Kvalitativ Studie om Flyktningfamiliers Erfaring med å gå fra Leie til å eie Bolig. Master's Thesis, Universitetet i Sørøst-Norge, Notodden, Norway, 2020.

44. EU-silc. Available online: https:/ / search.nsd.no/study/55e9ce51-608a-43b0-a466-7059d3646701 (accessed on 17 January 2022).

45. Rees, G.; Savahl, S.; Lee, B.J.; Casas, F. Children's Views on Their Lives and Well-Being in 35 Countries: A Report on the Children's Worlds Project, 2016-2019; Children's Worlds Project (ISCWeB): Jerusalem, Israel, 2020.

46. Statistikkbanken. Available online: https://statistikk.husbanken.no/kommune/nokkeltall (accessed on 14 August 2021).

47. Torgersen, U. Housing: The Wobbly Pillar under the Welfare State. Scand. Hous. Plan. Res. 1987, 4, 116-126. [CrossRef]

48. Nesheim, T.; Gressgård, L.; Hansen, K.; Neby, S. Gjenstridige problemer og tverretatlig samordning: Et analytisk rammeverk. Nor. Statsvitensk. Tidsskr. 2019, 35, 28-50. [CrossRef]

49. Rittel, H.W.J.; Webber, M.M. Dilemmas in a general theory of planning. Policy Sci. 1973, 4, 155-169. [CrossRef]

50. Hansen, T.; Nordvik, V.; Pedersen, A. Statens og Husbankens Rolle i en Markedsbasert Boligsektor: En Kunnskapsoversikt (Vol. 3/2007, Skriftserie (Norsk Institutt for Forskning om Oppvekst, Velferd og Aldring: Online)); Norsk Institutt for Forskning om Oppvekst, Velferd og Aldring: Oslo, Norway, 2007.

51. Denizou, K.; Grønseth, A.S.F.; Hauge, Å.L.; Stamsø, M. Eie Først_Barna Først. Hvilken Betydning har Selveid Bolig for Livskvaliteten $i$ Lavinntektsfamilier? SINTEF Academic Press: Trondheim, Norway, 2021. 